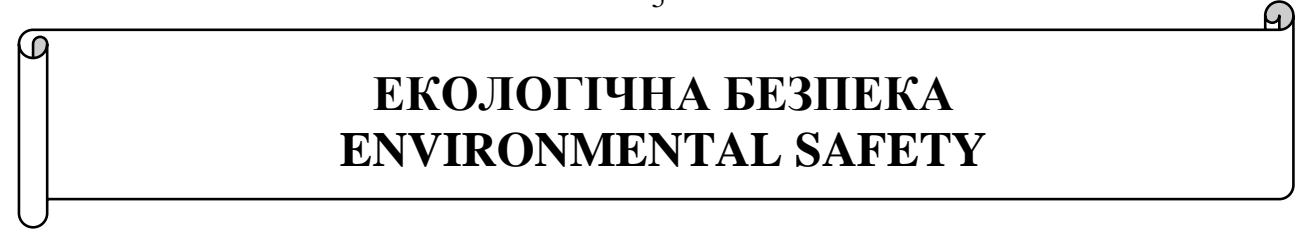

UDC 338.24:658:005.935:504

Oksana M. Hunchenko, $\mathrm{PhD}$ (Tech.), Professor

ORCID: 0000-0002-5769-2496 e-mail: gunchenko.oksana@gmail.com

Olena S. Voloshkina, Dr. Sc. (Tech.), Professor

ORCID: 0000-0002-3671-4449 e-mail: e.voloshki@gmail.com

Marina V. Kravchenko, $\mathrm{PhD}$ (Tech.), Associate Professor

ORCID: 0000-0003-0428-6440e-mail: marina-diek@ukr.net

Volodymyr I. Korinnyi, Assistant Professor

ORCID: 0000-0001-8486-7493 e-mail: korinnyi.vi@knuba.edu.ua

Kyiv National University of Construction and Architecture, Kyiv, Ukraine

\title{
ENVIRONMENTAL SAFETY MANAGEMENT SYSTEM - AS ONE OF THE COMPONENTS OF ENERGY EFFICIENCY
}

\begin{abstract}
The article substantiates the relationship between environmental safety and energy efficiency - as the main components on the way to sustainable development of society. The existing approaches to defining the essence of environmental safety are considered, its characteristic features are detailed, the basic practical principles of its provision are substantiated, and promising directions for the further development of the international environmental safety system are shown. The general scheme of the organization of the ecological safety system in the normal state of the environment is presented, which should be based on three components: control, regulation and implementation of safety measures. It is shown that maximum efforts should be directed to making management decisions based on the analysis of existing risks and forecasting new potential threats, which are an integral part of human activity. An important stage in a productive management system is the use of the best available technologies, which does not require strict regulation of activities and provides the freedom to choose ways to achieve this goal, based on the latest technological and technological solutions. organizational developments and their successful combination. Competitive advantages and a number of disadvantages from the introduction of an environmental management system at an enterprise, in particular in the energy sector, have been substantiated. The article presents the main laws of Ukraine in the field of environmental safety, as well as the state standards of Ukraine in the series of international standard ISO 14000. The main stages of management in the field of environmental safety, based on the Shuhard-Deming cycle, are summarized and presented in the model of the environmental safety management standard DSTU ISO 14001:2015.
\end{abstract}

Keywords: environmental safety; energy efficiency; management; sustainable development; best available technologies; legal framework

(c) О.М. Гунченко, О.С. Волошкіна, М.В. Кравченко, В.І. Корінний, 2020

ISSN: 2411-4049. Екологічна безпека та природокористування, № 4 (36), 2020 


\title{
О.М. Гунченко, О.С. Волошкіна, М.В. Кравченко, В.І. Корінний
}

Київський національний університет будівництва і архітектури, м. Київ, Україна

\section{СИСТЕМА МЕНЕДЖМЕНТУ ЕКОЛОГІЧНОЇ БЕЗПЕКИ - ЯК ОДНА ІЗ СКЛАДОВИХ ЕНЕРГЕТИЧНОЇ ЕФЕКТИВНОСТІ}

\begin{abstract}
Анотація. У статті обтрунтовано зв'язок між екологічною безпекою та енергетичною ефективністю - як основними складовими на шляху до сталого розвитку суспільства. Розглянуто існуючі підходи до визначення сутності екологічної безпеки, деталізовано ї̈ характерні риси, обтрунтовані основні практичні принципи ї̈ забезпечення, а також показані перспективні напрямки подальшого розвитку системи міжнародної екологічної безпеки. Наведено загальну схему організації системи екологічної безпеки при звичайному стані навколишнього середовища, яка має опиратися на три складові: контроль, регулювання і впровадження заходів безпеки. Показано, щчо максимальні зусилля мають бути зосереджені на прийнятті управлінських рішень на підставі аналізу існуючих ризиків та прогнозу нових потенційних загроз, які $є$ невід'ємною складовою діяльності людини. Важливим етапом продуктивної системи менеджменту є використання найліпших доступних технологій, який не потребує жорсткої регламентації діяльності та надає свободу вибору иляхів досягнення поставленої иілі, спираючись на надсучасні технологічні та організачійні розробки та їх вдале поєднання. Обтрунтовані конкурентні переваги та ряд недоліків від впровадження системи екологічного управління на підприємстві, зокрема в галузі енергетики. В роботі наведені базові закони України в галузі екологічної безпеки, а також державні стандарти Украӥни серї міжнародного стандарту ISO 14000. Узагальнено основні етапи менеджменту в сфері екологічної безпеки, які опираються на иикл Шухарда-Демінга та представлені в моделі системи управління екологічною безпекою за стандартом ДСТУ ISO 14001:2015.
\end{abstract}

Ключові слова: екологічна безпека; енергетична ефективність; менеджмент; сталий розвиток; найліпші доступні технологіі (НДТ); законодавча база

\section{Постановка проблеми}

На сучасному етапі розвитку цивілізації проблема взаємодії енергетики і довкілля набуває нових аспектів, впливаючи при цьому на великі території, на атмосферу й гідросферу Землі, а також на безпеку життєдіяльності людини.

Зростання масштабів розвитку енергопостачання й енергоспоживання в майбутньому зумовлюють подальше інтенсивне зростання їхнього всебічного впливу на всі компоненти екологічної безпеки в глобальному масштабі.

Тому постає проблема постійного контролю та управління рівнем екологічної безпеки в усіх сферах людської діяльності, у тому числі і в сфері енергетики.

Європейська агенція довкілля [1] виокремлює ряд екологічних проблем та секторів діяльності, серед яких $є$ галузь енергетики, та у яких проблеми екологічної безпеки i, особливо, система менеджменту екологічної безпеки потребують найбільшої уваги. 
Екологічна безпека безумовно впливає на якість життя людини та економічні й соціальні показники розвитку суспільства, тому потребує постійної актуалізації та корегування.

\section{Актуальність дослідження}

Головною метою екологічної безпеки держави є: розробка та впровадження концептуально обгрунтованої стратегії енергетичної ефективності, раціонального природокористування та захисту навколишнього середовища 3 метою створення гармонійного середовища для існування біологічного різноманіття та, головне, сталого розвитку суспільства. По суті своїй екологічна безпека $є$ запобіжником у питаннях вирішення екологічних проблем й основою створення передумов для збереження рівноваги між антропологічним впливом та природними катастрофами, зменшуючи їх обумовленість.

Енергетичний менеджмент - це постійно діюча система управління енергоспоживанням, яка дає змогу оптимізувати обсяги енерговитрат, прогнозувати i контролювати процеси вироблення, транспортування та використання необхідної кількості енергоресурсів для забезпечення ефективної господарської діяльності об'єктів господарювання. Це інструмент, який створює можливість скоротити споживання енергії, підвищити ефективність іï використання, а також знизити негативний вплив енергетики на довкілля, що входить в компетенції системи менеджменту екологічної безпеки [2].

На сьогоднішній день проблема забезпечення прийнятного стану навколишнього середовища набула глобального характеру і стоїть в переліку основних загроз для забезпечення сталого розвитку людства. Тому актуальність проблеми управління в сфері екологічної безпеки i, зокрема, в сфері енерговиробництва та енергоспоживання не викликає сумніву.

\section{Останні дослідження та публікації}

Питання екологічної безпеки, завдяки своїй актуальності, привертає на сьогодні увагу багатьох науковців.

Так, А.Б. Качинський у своїй роботі [3] виділяє ряд характерних рис екологічної безпеки:

- екологічна безпека виявляється у локальних, регіональних та глобальних масштабах;

- передбачає розумне задоволення екологічних потреб для всіх людей та суспільства і гарантує проживання в екологічно безпечному середовищі, яке сприяє безпечній життєдіяльності;

- розв'язання екологічних проблем дуже часто пов'язано 3 вирішенням інших аспектів національної безпеки;

- має суб'єктно-об'єктний характер, тобто має задовольняти інтереси як суспільства, так і навколишнього середовища;

- не може бути сформована через пригнічення чиїхось екологічних прав;

- має грунтуватись на фундаментальних еколого-соціальних та біосферних закономірностях, що мають комплексний характер. 
Основні практичні принципи забезпечення екологічної безпеки, запропоновані В.С. Луцько в роботі [4] ще у 2000 році, й сьогодні є актуальними, серед яких слід звернути увагу на такі:

- дотримування встановлених державою та пї суб'єктами допустимих рівнів впливу на навколишнє природне середовище і людину;

- проведення раціонального природокористування, при якому ресурсне забезпечення у рівній мірі задовольняє інтереси нині живучих і майбутніх поколінь;

- обов'язковість компенсації нанесених здоров'ю людини і природі втрат;

- адміністративно-територіальна та транскордонна відповідальність за шкоду екосистемам та населенню;

- своєчасне виявлення та відновлення порушених екосистем і природних комплексів;

- збереження біологічної різноманітності;

- дотримування розумної достатності й допустимості ризику при здійсненні будь-якої діяльності.

До числа глобальних екологічних проблем Є.П. Буравльов включає широкомасштабне забруднення океану; забруднення повітряного простору; знищення лісів; зменшення біологічної різноманітності та глобальні зміни клімату [5]. А серед головних перспективних напрямків подальшого розвитку системи міжнародної екологічної безпеки автор приділяє увагу таким: подальша глобалізація у відповідності з новими тенденціями та 3 пріоритетом сталого розвитку; розширення участі та підвищення ролі всіх регіональних, національних, міжурядових, неурядових організацій в діяльності по охороні довкілля; розширення співробітництва і кооперації в цій галузі; подальша інтеграція природоохоронної діяльності в рамках ООН та її установ, фінансова підтримка цих установ з боку розвинених країн.

У монографії [6] автором А.О. Олексюк було проведено дослідження та узагальнено підходи до тлумачень вченими суті екологічної безпеки 3 позиції врахування у ньому ключових об'єктів екологічної безпеки, згідно з якими деякі вчені розглядають екологічну безпеку з позицій відсутності зовнішніх загроз, а інші - виділяють серед об'єктів не лише людину, але і біосферу, що дає поєднання антропоцентричного та біоцентричного підходів.

В роботі [7] автором проведено обгрунтування екологічного менеджменту в контексті екологічної безпеки підприємства 3 визначенням інтегральних показників економічної безпеки підприємства.

\section{Формулювання цілей статті}

Мета роботи полягає в узагальненні змістовного наповнення екологічної безпеки в системі менеджменту підприємства, що є складовою системи глобальної екологічної безпеки та енергетичної ефективності, а також в обгрунтуванні основних етапів організації системи екологічної безпеки при звичайному стані навколишнього середовища. 


\section{Основна частина}

Екологічна безпека - це такий стан та умови навколишнього природного середовища, при якому забезпечується екологічна рівновага та гарантується захист навколишнього середовища: біосфери, атмосфери, гідросфери, літосфери, космосфери, видового складу тваринного і рослинного світу, природних ресурсів, збереження здоров'я і життєдіяльності людей [8].

Екологічна безпека має бути зорієнтованою на вирішення проблемних питань у своїй сфері як при звичайному стані системи, так і в умовах кризового, катастрофічного чи посткатастрофічного стану. Дії в цьому напрямку можуть бути ефективними завдяки прогнозуванню подій та розробці дерева подій і дерева ризиків.

Загальна схема організації системи екологічної безпеки при звичайному стані навколишнього середовища має спиратися на три складові:

- контроль;

- регулювання;

- розробку та впровадження заходів безпеки, які мають досить розгалужену систему (рис. 1), де в окрему галузь виділяється розвиток альтернативних джерел енергії.

Слід зазначити, що максимальні зусилля мають бути зосереджені на прийнятті управлінських рішень на підставі аналізу існуючих ризиків та прогнозу нових потенційних загроз, які є невід'ємною складовою діяльності людини, що стрімко трансформується та генерує нові форми впливу на оточуюче середовище і людину.

Сучасний тренд продуктивного менеджменту - це використання найліпших доступних технологій (НДТ), який не потребує жорсткої регламентації діяльності та надає свободу вибору шляхів досягнення поставленої цілі, спираючись на надсучасні технологічні та організаційні розробки та їх вдале поєднання.

Інтеграція крупних систем менеджменту $є$ інструментом, який більш коректно може бути застосований на великих підприємствах, орієнтованих на закордонні ринки збуту.

Для малих та середніх підприємств більш ефективним є впровадження НДТ, бо цей шлях дозволяє отримати зростання прибутковості та відносно низький період окупності і не потребує залучення фахівців із суміжних сфер менеджменту. Але процеси перетворення, модернізації, актуалізації в сфері екологічної безпеки є невідворотними, бо результатом вже накопичених та нових екологічних проблем є зниження якості життя населення, збільшення захворюваності та передчасних летальних наслідків i, як наслідок, - зниження темпів економічного зростання. Фахівці оцінюють щорічні збитки від деградації навколишнього середовища на рівні 4-6\% ВВП.

У якості сучасних загрозливих викликів також слід згадати старіння нації, збільшення навантаження на працездатне населення, неконтрольовані міграційні процеси, зміну орієнтирів розвитку для нових поколінь, появу нових технологічних розробок, ускладнення виробничих процесів, використання діджитал-платформ та появу нових професій, що створює запит на нові знання та навички. 


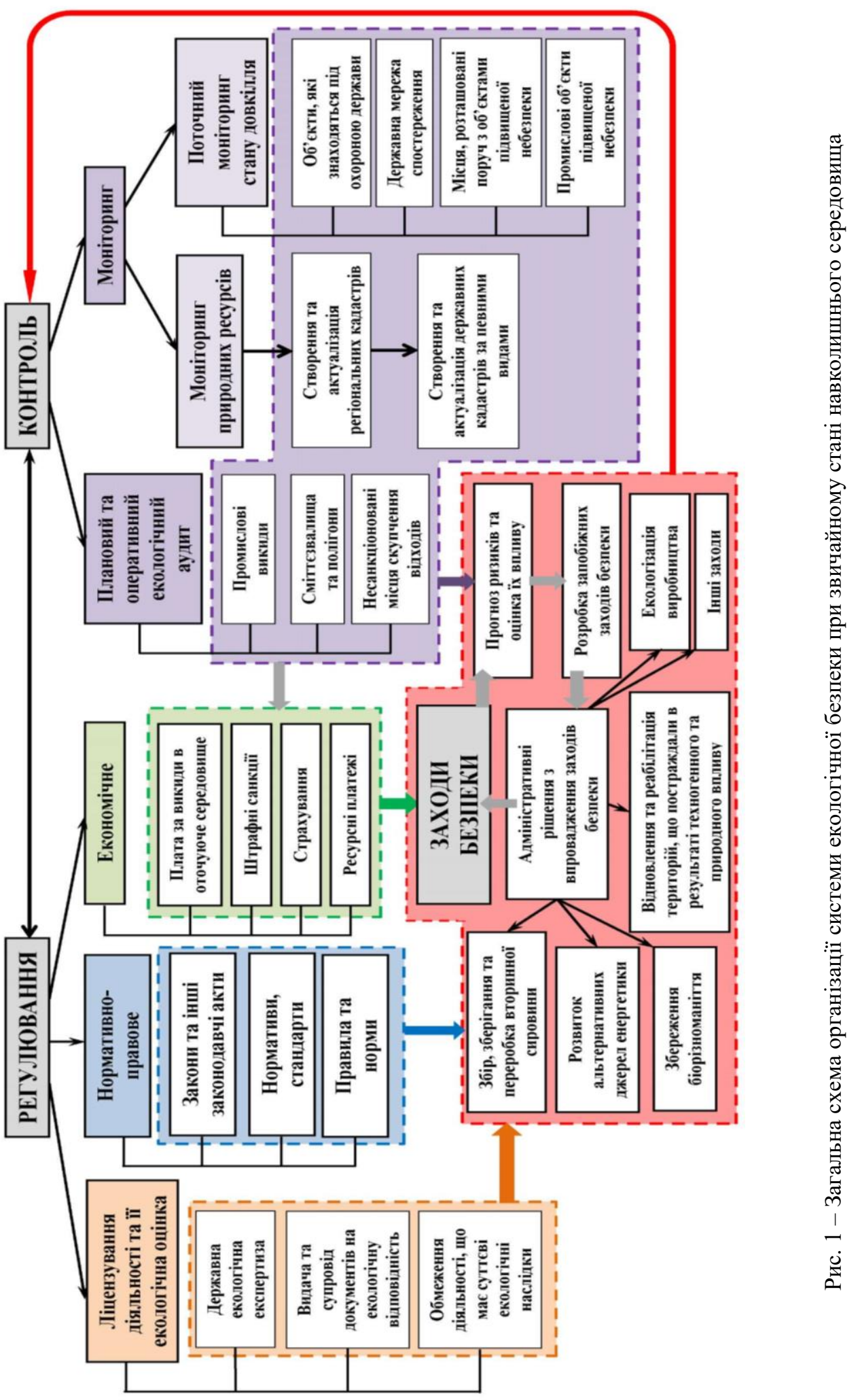


Система менеджменту екологічної безпеки підприємства є складовою системи глобальної екологічної безпеки, так як екологічні загрози все частіше розширюють зони впливу за межі локалізації осередку впливу та 3 легкістю долають адміністративні кордони, тому неузгодженість законодавства різних країн чи напрямків діяльності стає додатковим фактором збільшення загрози та створює перешкоди для реалізації прийнятих адміністративних рішень.

Україна впевнено намагається інтегруватися до системи міжнародної безпеки, одним з аспектів якої є екологічна безпека. На сьогодні в Україні діє низка нормативних документів, що регламентують вирішення екологічних питань на глобальному рівні, це - фундаментальні закони в галузі екологічної безпеки, стандарти серії ISO 14000 та нормативні документи на рівні промислових галузей (табл. 1, табл. 2).

Таблиця 1 - Базові закони України в галузі екологічної безпеки

\begin{tabular}{|c|c|c|}
\hline Назва & $\begin{array}{c}\text { Дата } \\
\text { прийняття }\end{array}$ & $\begin{array}{l}\text { Початок } \\
\text { дії } \\
\text { останньої } \\
\text { редакції }\end{array}$ \\
\hline 1 & 2 & 3 \\
\hline $\begin{array}{l}\text { Закон України від 26.06.1991 № 1268-XII «Про охорону } \\
\text { навколишнього природного середовища» }\end{array}$ & 26.06.1991 & 16.10 .2020 \\
\hline Земельний кодекс України від 20.12.2001 № 2905-III & 20.12 .2001 & 16.10 .2020 \\
\hline Водний кодекс України від 06.06.95 № 214/95-ВР & 06.06 .1995 & 16.10 .2020 \\
\hline Кодекс про надра України від 27.07.94 № 133/94-ВР & 27.07.1994 & 16.10 .2020 \\
\hline Лісовий кодекс України від 21.01.94 № 3853-XII & 21.01.1994 & 03.07.2020 \\
\hline $\begin{array}{l}\text { Закон України «Про охорону атмосферного повітря» } \\
\text { № 2708-XII від 16.10.92 }\end{array}$ & 16.10 .1992 & 16.10 .2020 \\
\hline $\begin{array}{l}\text { Закон України «Про тваринний світ» від 13.12.2001 } \\
\text { № 2894-III }\end{array}$ & 13.12.2001 & 07.06 .2020 \\
\hline $\begin{array}{l}\text { Закон України «Про рослинний світ» від 09.04.1999 } \\
\text { № 591-XIV }\end{array}$ & 09.04.1999 & 07.06 .2020 \\
\hline $\begin{array}{l}\text { Закон України від 28.02.2019 № 2697-VIII «Про Основні } \\
\text { засади (стратегію) державної екологічної політики } \\
\text { України на період до } 2030 \text { року» }\end{array}$ & 28.02.2019 & 01.01 .2020 \\
\hline $\begin{array}{l}\text { Закон України від 23.05.2017 № 2059-VIII «Про оцінку } \\
\text { впливу на довкілля» }\end{array}$ & 23.05.2017 & 17.07.2020 \\
\hline $\begin{array}{l}\text { Закон України від 20.03.2018 № 2354-VIII } \\
\text { «Про стратегічну екологічну оцінку» }\end{array}$ & 20.03.2018 & 01.01 .2020 \\
\hline $\begin{array}{l}\text { Закон України від 01.07.2015 № 562-VIII «Про } \\
\text { ратифікацію Протоколу про стратегічну екологічну } \\
\text { оцінку до Конвенції про оцінку впливу на навколишнє } \\
\text { середовище у транскордонному контексті» }\end{array}$ & 01.07 .2015 & 26.07.2015 \\
\hline
\end{tabular}


Продовження таблиці 1

\begin{tabular}{|l|c|c|}
\hline \multicolumn{1}{|c|}{1} & 2 & 3 \\
\hline $\begin{array}{l}\text { ДСТУ-Н Б Б.1.1-10:2010 Настанова з виконання розділів } \\
\text { «Охорона навколишнього природного середовища у } \\
\text { складі містобудівної документації. Склад та вимоги» }\end{array}$ & 28.12 .2010 & 01.10 .2011 \\
\hline $\begin{array}{l}\text { дСТУ 7738:2015 «Безпека екологічна та техногенна. } \\
\text { Терміни та визначення понять» }\end{array}$ & 22.06 .2015 & 01.01 .2016 \\
\hline $\begin{array}{l}\text { Постанова від 31.10.2018 № 913 «Про затвердження } \\
\text { критеріїв, за якими оцінюється ступінь ризику від } \\
\text { провадження господарської діяльності у сфері } \\
\text { геологічного вивчення та раціонального використання } \\
\text { надр і визначається періодичність здійснення планових } \\
\text { заходів державного нагляду (контролю) Державною } \\
\text { службою геології та надр» }\end{array}$ & 31.10 .2018 & 14.11 .2018 \\
\hline $\begin{array}{l}\text { Постанова від 05.03.1998 № 188/98-ВР «Про Основні } \\
\text { напрями державної політики України у галузі охорони } \\
\text { довкілля, використання природних ресурсів та } \\
\text { забезпечення екологічної безпеки» }\end{array}$ & 05.03 .1998 & 05.03 .1998 \\
\hline $\begin{array}{l}\text { Конвенція «Про доступ до інформації, участь } \\
\text { громадськості в процесі прийняття рішень та доступ до } \\
\text { правосуддя з питань, що стосуються довкілля» }\end{array}$ & 25.06 .1998 & 27.05 .2005 \\
\hline
\end{tabular}

Таблиця 2 - Державні стандарти України серії ISO 14000

\begin{tabular}{|l|c|c|}
\hline \multicolumn{1}{|c|}{ Назва } & \multicolumn{1}{|c|}{$\begin{array}{c}\text { Дата } \\
\text { прийняття }\end{array}$} & $\begin{array}{c}\text { Початок } \\
\text { дії }\end{array}$ \\
\hline \multicolumn{1}{|c|}{1} & 2 & 3 \\
\hline $\begin{array}{l}\text { ДСТУ ISO 14001:2015 Системи екологічного } \\
\text { управління. Вимоги та настанови щодо застосовування } \\
\text { (ISO 14001:2015, IDT) }\end{array}$ & 21.12 .2015 & 01.07 .2016 \\
\hline $\begin{array}{l}\text { ДСТУ ISO 14004:2016 Системи екологічного } \\
\text { управління. Загальні настанови щодо запроваджування } \\
\text { (ISO 14004:2016, IDT) }\end{array}$ & 13.12 .2016 & 01.10 .2017 \\
\hline $\begin{array}{l}\text { ДСТУ ISO 14005:2015 Системи екологічного управління. } \\
\text { Настанови щодо поетапного запровадження системи } \\
\text { екологічного управління, використовуючи оцінювання } \\
\text { екологічних характеристик (ІSО 14005:2010, IDT) }\end{array}$ & 21.12 .2015 & 01.01 .2017 \\
\hline $\begin{array}{l}\text { ДСТУ ISO 14015:2005 Екологічне управління. } \\
\text { Екологічне оцінювання ділянок та організацій } \\
\text { (ISO 14015:2001, IDT) }\end{array}$ & 30.06 .2005 & 01.08 .2007 \\
\hline $\begin{array}{l}\text { ДСТУ ISO 14020:2003. Екологічні марковання та } \\
\text { декларації. Загальні принципи }\end{array}$ & 11.06 .2003 & 01.07 .2004 \\
\hline $\begin{array}{l}\text { ДСТУ ISO 14021:2016 Екологічні марковання та } \\
\text { декларації. Екологічні самодекларації (екологічне } \\
\text { маркування типу II) (ISO 14021:2016, IDT) }\end{array}$ & 13.12 .2016 & 01.10 .2017 \\
\hline
\end{tabular}


Продовження таблиці 2

\begin{tabular}{|l|c|c|}
\hline \multicolumn{1}{|c|}{1} & 2 & 3 \\
\hline $\begin{array}{l}\text { ДСТУ ISO 14024:2002 Екологічні марковання та } \\
\text { декларації. Екологічне маркуванння типу I. Принципи та } \\
\text { методи }\end{array}$ & 18.09 .2002 & 01.07 .2004 \\
\hline $\begin{array}{l}\text { ДСТУ ISO 14031:2016 Екологічне управління. } \\
\text { Оцінювання екологічної дієвості. Настанови } \\
\text { (ISO 14031:2013, IDT) }\end{array}$ & 13.12 .2016 & 01.10 .2017 \\
\hline $\begin{array}{l}\text { ДСТУ ISO/TS 14033:2016 Екологічне управління. } \\
\text { Кількісна екологічна інформація. Настанови та приклади } \\
\text { (ISO/TS 14033:2012, IDT) }\end{array}$ & 13.12 .2016 & 01.10 .2017 \\
\hline $\begin{array}{l}\text { ДСТУ ISO 14040:2013 Екологічне управління. } \\
\text { Оцінювання життєвого циклу. Принципи та структура } \\
\text { (ISO 14040:2006, IDT) }\end{array}$ & 29.11 .2013 & 01.07 .2014 \\
\hline $\begin{array}{l}\text { ДСТУ ISO 14041:2004. Екологічне керування } \\
\text { оцінювання життєвого циклу. Визначання цілі і сфери } \\
\text { застосування та аналізування інвентаризації } \\
\text { (ISO 14041:1998, IDT) }\end{array}$ & 02.08 .2004 & 01.01 .2006 \\
\hline $\begin{array}{l}\text { ДСТУ ISO 14044:2013 Екологічне управління. } \\
\text { Оцінювання життєвого циклу. Вимоги та настанови } \\
\text { (ISO 14044:2006, IDT) }\end{array}$ & 09.01 .2013 & 01.07 .2014 \\
\hline $\begin{array}{l}\text { ДСТУ ISO 14050:2016 Екологічне управління. Словник } \\
\text { термінів (ISO 14050:2009, IDT) }\end{array}$ & 30.03 .2016 & 01.07 .2017 \\
\hline $\begin{array}{l}\text { ДСТУ ISO 14051:2015 Екологічне управління. } \\
\text { Обліковування витрат, пов`язаних із матеріальними } \\
\text { потоками. Загальні принципи та структура } \\
\text { (ISO 14051:2011, IDT) }\end{array}$ & 21.12 .2015 & 01.01 .2017 \\
\hline $\begin{array}{l}\text { ДСТУ ISO/ТR 14062:2006 Екологічне управління. } \\
\text { Враховування екологічних аспектів у проектуванні та } \\
\text { розроблянні продукції (ISО/ТR 14062:2002, IDT) }\end{array}$ & 27.12 .2006 & 01.01 .2008 \\
\hline
\end{tabular}

Згідно 3 міжнародним стандартом ISO 14001, впроваджуються системи екологічного менеджменту як частини загальної системи менеджменту, що дозволяє встановити екологічні аспекти організації та їх вплив на навколишнє природне середовище, забезпечує порядок i послідовність вирішення підприємством екологічних проблем, з використанням таких інструментів, як екологічна політика; планування природоохоронної діяльності відповідно до прийнятої екологічної політики; організація діяльності в системі екологічного менеджменту; внутрішні перевірки і коригування діяльності; аналіз результатів роботи та перегляд системи екологічного менеджменту; демонстрація досягнутих у системі екологічного менеджменту результатів та їх послідовне поліпшення [9].

Менеджмент в сфері екологічної безпеки спирається на цикл ШухардаДемінга (PDCA), як і системи менеджменту якості й безпеки і гігієни виробничих процесів, та передбачає неперервний циклічний процес, що надає можливість організації розробити, запровадити і підтримувати екологічну політику, в основу якої покладено лідерство та зобов'язання найвищого 
керівництва щодо системи екологічного управління [10]. Основні етапи цього процесу є стандартними та реалізуються у такій послідовності:

1. Планування (Р) - встановлення цілей та процесів, необхідних для отримання результатів, що відповідають екологічній політиці організації.

2. Підтримка функціонування (D) - запровадження процесів.

3. Оцінка дієвості (C) - відстеження і вимірювання процесів, зважаючи на екологічну політику, цілі, завдання, правові та інші вимоги, а також складання звітної документації про їі результати.

4. Запровадження дій (А) - впровадження заходів для постійного поліпшення характеристик системи екологічного менеджменту.

Модель системи управління екологічною безпекою за стандартом ДСТУ ISO 14001:2015 наведена на рис. 2.

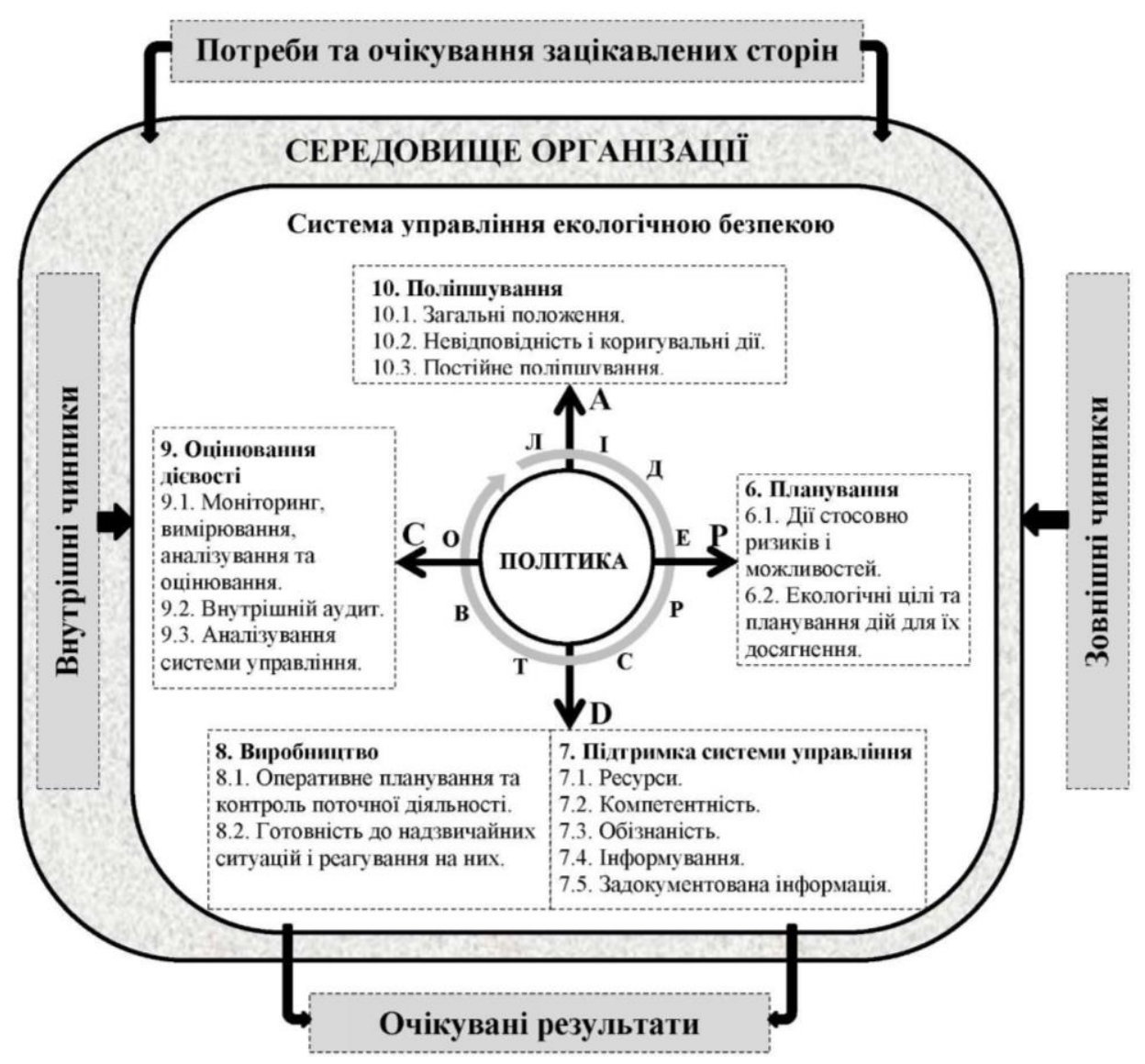

Рис. 2 - Модель системи управління екологічною безпекою за стандартом ДСТУ ISO 14001:2015 [10]

Описані етапи співпадають 3 системою управління безпекою і гігієною виробничих процесів, так як обидві ці системи побудовані на базі системи управління якістю за стандартом ISO 9001 та можуть використовуватись підприємством одночасно чи створювати інтегровані системи менеджменту різних за конфігураціями та охопленням сфер впливу. 
Екологічна безпека - це, з одного боку, стан захищеності від негативних факторів внутрішнього та зовнішнього середовища, з іншого - його здатність швидко усувати загрози та забезпечувати своє функціонування на основі ефективних техніко-технологічних та управлінських інновацій.

Впровадження системи екологічного управління підприємства, зокрема в галузі енергетики, додає йому ряд конкурентних переваг:

- поліпшення іміджу підприємства на регіональному і міжнародному рівні та розширення ринків збуту;

- економія енерго- та водоспоживання;

- зниження виплат при зменшенні утворення відходів;

- захист від штрафів і невдоволення з боку громадськості;

- підвищення статусу соціально відповідального виробництва;

- вирішення екологічних проблем з мінімальними фінансовими витратами.

Можливі недоліки:

- значна робота з отримання і збереження сертифікації;

- витрати зі збереження сертифікації;

- потенційна втрата сертифікації.

Стрімкий розвиток та впровадження зазначеного стандарту 3330 тис. сертифікатів у 1999 році до майже 11 млн у 2016 році та зниження їх кількості до 10,5 млн у 2017 році безумовно сприяло впровадженню нових форм організації виробництва, підвищенню якості продукції та розробці інших стандартів ISO, таких як ISO 14001, кількість сертифікатів за яким збільшилась у 25,6 разів за цей же період (рис. 3).

Вказана тенденція до зростання характерна і для країн Свропи та України, але якщо для розвинених країн Свропи характерним було поступове зростання 3 незначним зниженням, то в Україні цей процес є доволі не прогнозованим, хоча й має тенденцію до зростання (рис. 4).

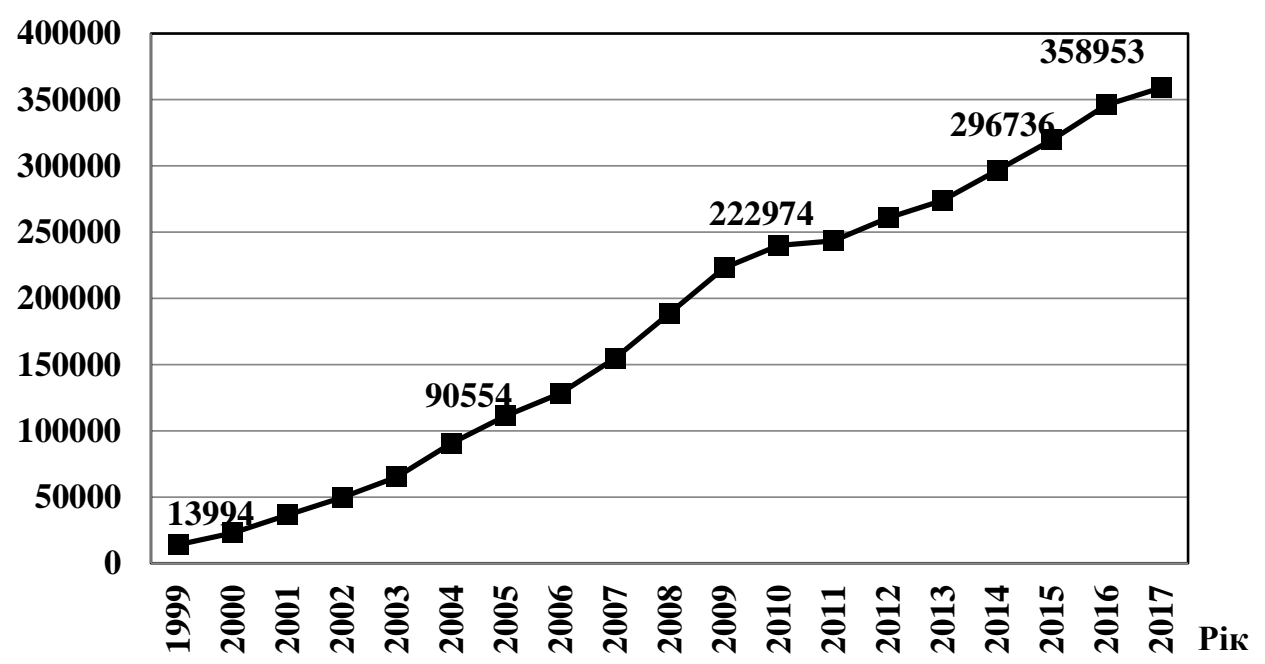

Рис. 3 - Кількість сертифікованих підприємств за стандартом ISO 14001 в світі 31999 р. по 2017 р. [11] 


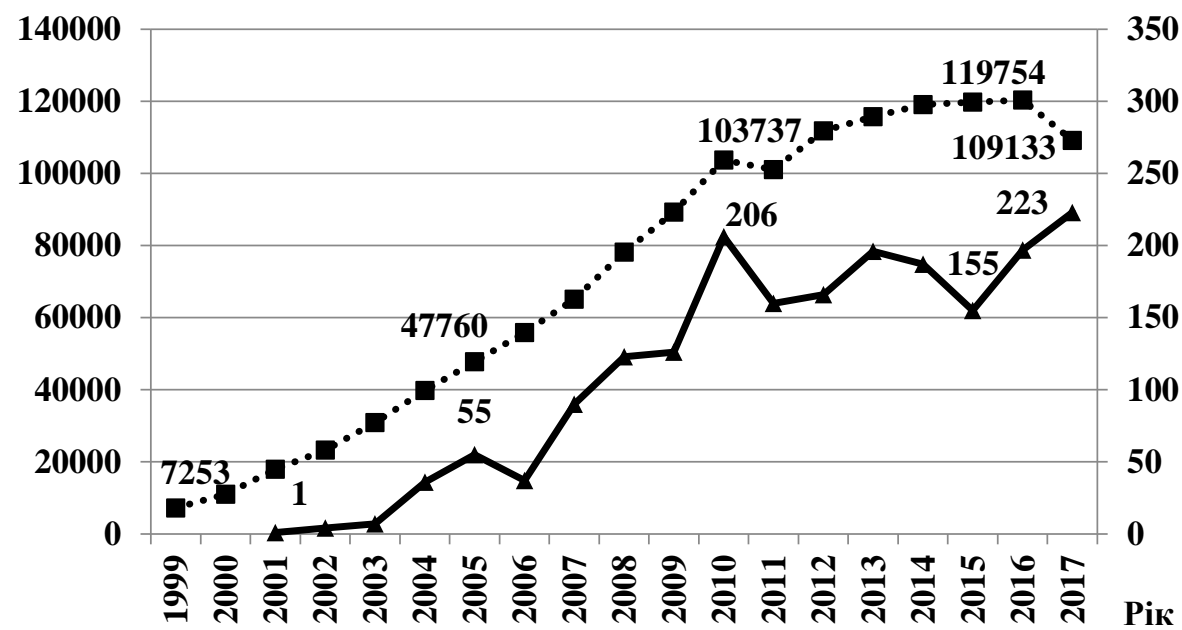

-..- Кількість сертифікатив в Свропі
- Кількість сертифікатів в Україні

Рис. 4 - Кількість сертифікованих підприємств за стандартом ISO 14001 в Свропі та Україні з 1999 р. по 2017 р. [11]

За час 3 моменту впровадження зазначеного стандарту вперше світ докорінно змінився, але пріоритетною й досі є спрямованість на екологізацію та безпеку. Тому, більше 10000 провідних компаній по всьому світу, в тому числі великі американські компанії, такі як Ford i IBM, були сертифіковані на відповідність стандарту ISO 14001. Тиск, що утворюється на ринках збуту, сприяє більш широкому впровадженню міжнародних екологічних стандартів, та все більше компаній вважають їх необхідним бізнес-інструментом.

Найбільша кількість сертифікатів за стандартом ISO 14001 в країнах Східної Азії й басейну Тихого океану - 59,8\% та Європи - 30,4\% від загальної кількості в світі [11]. Серед Європейських країн лідерами є Великобританія, Італія, Іспанія, Німеччина та Франція з загальною кількістю у 56,6\%, Україна ж хоч і пройшла шлях від 1 до 223 сертифікатів за останні 18 років, але ця кількість складає лише 0,2\% серед країн Європи (табл. 3).

Таблиця 3 - Країни-лідери в сертифікації за стандартом ISO 14001 серед Європейських країн у порівнянні з Україною [12]

\begin{tabular}{|l|c|c|c|c|}
\hline \multirow{2}{*}{\multicolumn{1}{|c|}{ Країна }} & \multicolumn{3}{|c|}{ Рік } & \multirow{2}{*}{ У відсотках до } \\
\cline { 2 - 3 } загальної кількості
\end{tabular}

У розвинених індустріальних країнах ринковий тиск $є$ рушійною, але вже не основною причиною, по якій більшість компаній звертаються за сертифікацією, 
бо прибутковість і соціальна відповідальність, як і раніше, є переконливими причинами того, щоб компанія пройшла реєстрацію відповідності до ISO 14001. Аналіз відкритих джерел вказує на те, що найчастіше сертифікацію в напрямку екологічної безпеки використовують підприємства будівельної галузі $(18,6 \%)$; виробництва готових металевих виробів $(9,48 \%)$ та електричного і оптичного обладнання (9,3\%), а також сфера оптової та роздрібної торгівлі й ремонту автомобілів та побутової техніки (8,65\%), що разом складає приблизно 46\%.

\section{Висновки та перспективи подальших досліджень}

За останні роки було розроблено декілька систем менеджменту, найпоширенішими 3 яких стали системи управління якістю, екологічною безпекою, управління в сфері енергетики, охороною здоров'я та безпекою праці, інформаційною безпекою та безпекою харчових продуктів. Досягти екологічної безпеки країни в цілому можна лише за умови розвитку ефективної системи екологічного менеджменту, що є складовою енергетичної безпеки в усіх аспектах і складових її ефективності.

Ефективна система управління екологічною безпекою, зокрема і в сфері енергоефективності, дозволить оперативно планувати та контролювати поточну діяльність, реагувати вчасно на надзвичайні ситуації, їх якісно вирішувати та, що саме головне, дозволить впевнено крокувати на шляху до сталого розвитку людства.

На сьогодні склалась унікальна сприятлива ситуація для створення інтегрованих систем менеджменту на базі об'єднання трьох базових систем за стандартами ISO 9001, ISO 14001, ISO 45001, перехід до якого зі стандарту OHSAS 18001 почався з березня 2018 року та має відбутися за найближчі три роки. Впровадження ISO 45001 та те, що сертифікація за стандартами ISO 9001 й ISO 14001, знаходячись на піку актуальності, у контексті сталого розвитку у 2017 році дещо втратили свої позиції, створює передумови для їх об'єднання 3 урахуванням доцільності для певної галузі виробництва.

Розглянуті в статті загальні положення щодо визначення сутності екологічної безпеки та іiі місця в системі менеджменту підприємства потребують подальшого розвитку. Зокрема, актуальними залишаються проблеми якісного формування системи менеджменту екологічною безпекою, організаційного та кадрового забезпечення цих процесів, а також проблеми дієвих нормативних й законодавчих документів в сфері екологічної безпеки нашої держави.

\section{СПИСОК ЛІТРАТУРИ}

1. Європейське агентство 3 охорони навколишнього природного середовища [Електронний ресурc]. - Режим доступу: https://www.eea.europa.eu/ru. Дата звернення 23-10-2020.

2. Маляренко В. А. Енергетика і навколишне середовище: наукове видання / В. А. Маляренко. - Харків: вид-во САГА, 2008. - 364 с.

3. Качинський А. Б. Екологічна безпека України: системний аналіз перспектив покращення / А. Б. Качинський. К.: НІСД, 2001. - 312 с.

4. Луцько В. С. Економічні важелі забезпечення екологічної безпеки України /

В. С. Луцько. - К.: «Чорнобильінтерінформ», 2000. - 126 с.

5. Буравльов С. П. Глобалізація: проблеми безпеки / С. П. Буравльов. - К.: Інститут проблем національної безпеки, 2007. - 160 с. 
6. Герасимчук 3. В., Олексюк А. О. Екологічна безпека регіону: діагностика та механізм забезпечення: монографія / 3. В. Герасимчук, А. О. Олексюк. - Луцьк: Надстир'я, 2007. - 280 с.

7. Акуленко В. Л. Екологічний менеджмент в контексті забезпечення екологічної безпеки підприємства / В. Л. Акуленко, І. В. Мамчук // Вісник Хмельницького національного університету. - 2009. - Т. 1, № 5. - С. 21-26.

8. Закон України № 1268-XII «Про охорону навколишнього природного середовища» від 26 червня 1991 року [Електронний ресурс]. - Режим доступу: https://zakon.rada.gov.ua/laws/show/1264-12\#Text. Дата звернення 26-10-2020.

9. Черчик Л. Екологічна безпека в системі менеджменту підприємства / Л. Черчик // Економічний часопис Східноєвропейського національного університету імені Лесі Українки. - 2019. - №1. - С. 55-61.

10. ДСТУ ISO 14001:2015 Системи екологічного керування. Вимоги та настанови щодо застосування. - Чинні від 21.12.2015. - Київ: ДП «УкрНДНЦ», 2016. - 38 с.

11. ISO Survey of certifications to management system standards - Full results. [Електронний ресурс]. - Режим доступу: https://isotc.iso.org/livelink/livelink?func= $11 \&$ objId=18808772\&objAction=browse\&viewType=1 - - Дата звернення: 10.05.2019.

12. Буркинський Б. В. Наукові засади розробки стратегії сталого розвитку України: монографія / Б. В. Буркинський. - Одеса: ІПРЕЕД НАН України, 2012. - 714 с.

Стаття надійшла до редакиії 10.06.2020 і прийнята до друку після рещензування 24.09.2020

\section{REFERENCES}

1. European Agency for Environmental Protection. Retrieved 23 October 2020 from: https://www.eea.europa.eu/ru. (in Ukrainian).

2. Maliarenko, V.A. (2008). Energy and environment: a scientific publication. Kharkiv: SAGA. (in Ukrainian).

3. Kachinskij, A.B. (2001). Ecological safety of Ukraine: system analysis of prospects for improvement. Kyiv: NISS. (in Ukrainian).

4. Lutsko, V.S. (2000). Economic levers of ensuring ecological safety of Ukraine. Kyiv: Chornobylinterinform. (in Ukrainian).

5. Buravlov, Ye.P. (2007). Globalization: security issues. Kyiv: Instytut problem natsionalnoi bezpeky. (in Ukrainian).

6. Gerasymchuk, Z.V., \& Oleksyuk, A.A. (2007). Ecological safety of the region: diagnostics and maintenance mechanism: monograph. Lutsk: Nadstyria. (in Ukrainian).

7. Akulenko, V.L., \& Mamchuk, I.V. (2009). Ecological management in the context of providing ecological safety of the enterprise. Visnyk of Khmelnytsky National University (Ukraine), 1(5), 21-26.

8. On Environmental Protection: Law of Ukraine (1991). Retrieved 26 October 2020 from: https://zakon.rada.gov.ua/laws/show/1264-12\#Text. (in Ukrainian).

9. Cherchyk, L. (2019). Ecological safety in the enterprise management system. Economic Journal of the Lesia Ukrainka East European National University (Ukraine), 1, 55-61.

10. Environmental management systems. Requirements and guidelines for use: DSTU ISO 14001:2015 (2016). Kyiv: SE "UkrNDNC". (in Ukrainian).

11. Survey of certifications to management system standards: ISO 14001:2004 (2004). Retrieved 10 May 2019 from: https://isotc.iso.org/livelink/livelink?func=ll\&objId= 18808772 \&objAction=browse\&viewType $=1$. (in Russian).

12. Burkinsky, B.V. (2012). Scientific principles of development strategy of sustainable development of Ukraine: monograph. Odessa: IPREED NAS of Ukraine. (in Ukrainian).

The article was received 10.06.2020 and was accepted after revision 24.09.2020 


\section{Гунченко Оксана Миколаївна}

кандидат технічних наук, професор кафедри охорони праці та навколишнього середовища Київського національного університету будівництва та архітектури

Адреса робоча: 03037 Україна, м. Київ, проспект Повітрофлотський, 31

ORCID: 0000-0002-5769-2496 e-mail: gunchenko.oksana@gmail.com

\section{Волошкіна Олена Семенівна}

доктор технічних наук, завідувач кафедри охорони праці та навколишнього середовища Київського національного університету будівництва та архітектури

Адреса робоча: 03037 Україна, м. Київ, проспект Повітрофлотський, 31

ORCID: 0000-0002-3671-4449 e-mail: e.voloshki@gmail.com

\section{Кравченко Марина Василівна}

кандидат технічних наук, доцент кафедри охорони праці та навколишнього середовища Київського національного університету будівництва і архітектури

Адреса робоча: 03037 Україна, м. Київ, проспект Повітрофлотський, 31

ORCID: 0000-0003-0428-6440e-mail: marina-diek@ukr.net

\section{Корінний Володимир Ілліч}

старший викладач кафедри охорони праці і навколишнього середовища Київського національного університету будівництва і архітектури

Адреса робоча: 03037 Україна, м. Київ, проспект Повітрофлотський, 31

ORCID: 0000-0001-8486-7493 e-mail: korinnyi.vi@knuba.edu.ua 